\title{
Ocena stopnia antropopresji wód podziemnych w rejonach poszukiwania i eksploatacji złóż węglowodorów
}

\author{
Ewa Krogulec ${ }^{1}$, Katarzyna Sawicka ${ }^{1}$, Sebastian Zabłocki ${ }^{1}$
}

\begin{abstract}
Assessment of the anthropopressure degree of groundwater in the areas of hydrocarbon exploration and exploitation. Prz. Geol., 68: 242-248; doi: 10.7306./2020.11

A b s t r a c t. The aim of the study was to propose a range of interpretation of the results of qualitative groundwater monitoring by using geochemical indicators to assess the degree of anthropogenic groundwater pollution. The location, scope and frequency of groundwater testing dedicated to the possibility of indicating the degree of pressure resulting from the activity in the field of hydrocarbon exploration and exploitation is proposed. On the basis of multi-stage monitoring research in the area of hydrocarbon exploration and exploitation, the qualitative groundwater base state was determined and change trends were characterized at each subsequent testing stage. Anthropogenic transformations of groundwater chemistry are the result of many overlapping factors, which is why the reason of water quality change is difficult to identify. The very statement of the presence of high values of physico-chemical parameters in waters does not have to prove the influence of the monitored object on their composition. It is proposed to use geochemical indicators: enrichment factor, pollution factor, geoaccumulation factor, and pollution load indicator to assess the degree of anthropogenic pollution of groundwater in the area of hydrocarbon exploration and exploitation. The geochemical indicators, which are proposed for use, enable the identification of substances of anthropogenic origin in waters and the detection of even the initial degree of anthropopressure on their composition in specific mining activities.
\end{abstract}

Keywords: groundwater, dedicated monitoring, hydrocarbon deposits, anthropogenic pollution, geochemical indicators

Badania monitoringowe stanów i jakości wód podziemnych w rejonach prowadzonej działalności górniczej w zakresie poszukiwania i eksploatacji węglowodorów są zasadniczym elementem oceny ich wpływu na środowisko naturalne. Ocena istniejących lub potencjalnych oddziaływań antropogenicznych na wody podziemne wymaga retrospektywnej analizy przemian, zrealizowanej poprzez porównanie danych monitoringowych z różnych przedziałów czasowych i faz realizacji działalności górniczej. Funkcjonowanie sieci monitoringowej w rejonach dzialalności górniczej pozwaljace na potencjalnego oddziaływania na wybrane komponenty środowiska powinno zostać odpowiednio zaplanowane i zaprojektowane (Krogulec, Sawicka, 2013, 2014, 2015). Wymaga rozwiązań przeznaczonych do konkretnej działalności w zakresie lokalizacji punktów monitoringowych, ich rodzaju, częstotliwości oraz zakresu pomiarów i opróbowania wód.

Podstawowym celem wykonywania badań monitoringowych wód podziemnych jest ocena jakości i stanów wód, śledzenie zmian w celu rozpoznania zagrożeń. Obowiązujące regulacje prawne dotyczące monitoringu wód podziemnych, czyli Rozporządzenie Ministra Zdrowia z dn. 7 grudnia 2017 r. w sprawie jakości wody przeznaczonej do spożycia przez ludzi (Rozporządzenie, 2017) i Ministra Gospodarki Morskiej i Żeglugi Śródlądowej z dn. 11 października 2019 r. w sprawie kryteriów i sposobu oceny stanu jednolitych części wód podziemnych (Rozporządzenie, 2019), regulują zakres obserwacji wód podziemnych wykorzystywanych w określonych zadaniach hydrogeologicznych. Zgodnie z zawartymi w nich zapisami, badania monitoringowe są prowadzone w celach diagnostycznych i operacyjnych, do tworzenia baz danych, oceny trendów zmian oraz określenia wpływu oddziaływań wynikających z warunków naturalnych i oddziaływań antropogenicznych. Pomi- jane jest natomiast znaczenie tła hydrogeochemicznego i stanu bazowego środowiska wodnego jako poziomów odniesienia w obserwacji zmian składu chemicznego wód podziemnych, które zachodzą pod wpływem działalności człowieka. Retrospektywny charakter analizy w przypadku konkretnej działalności górniczej, jaką są prace poszukiwawcze i rozpoznawcze oraz eksploatacja węglowodorów, wymaga przede wszystkim oceny jakościowego stanu bazowego wód podziemnych. Antropogeniczne przekształcenia chemizmu wód podziemnych są zazwyczaj skutkiem wielu nakładających się przyczyn, a pogarszanie się jakości wód rzadko bywa szybko i łatwo identyfikowane tylko na podstawie ogólnych badań składu chemicznego. Ocena stopnia antropopresji prowadzonej działalności jest możliwa poprzez obliczenia wybranych wskaźników geochemicznych, które mogą ilościowo identyfikować substancje pochodzenia antropogenicznego w wodach oraz wskazywać nawet początkowy etap antropopresji.

\section{TEREN I ZAKRES BADAŃ}

Obszarem badań jest teren górniczy, na którym odbywało się otworowe poszukiwanie złóż węglowodorów. Jest on położony ok. $15 \mathrm{~km}$ na północny zachód od Wejherowa (woj. pomorskie) (ryc. 1), znajduje się na Wysoczyźnie Żarnowieckiej i sąsiaduje od zachodu z Doliną Piaśnicy. Na terenie badań zaprojektowano modelowy system monitoringu wód podziemnych, przeznaczony do oceny potencjalnego wpływu poszukiwań węglowodorów na wody podziemne na każdym etapie prowadzonych wierceń. Działająca w latach 2011-2018 sieć monitoringowa składała się z punktów obserwacyjnych położonych w bezpośrednim otoczeniu placu wiertni (monitoring lokalny), a także zlokalizowanych w rejonie Wysoczyzny Żarnowieckiej oraz

\footnotetext{
${ }^{1}$ Wydział Geologii, Uniwersytet Warszawski, ul. Żwirki i Wigury 93, 02-089 Warszawa; Ewa.Krogulec@uw.edu.pl
} 


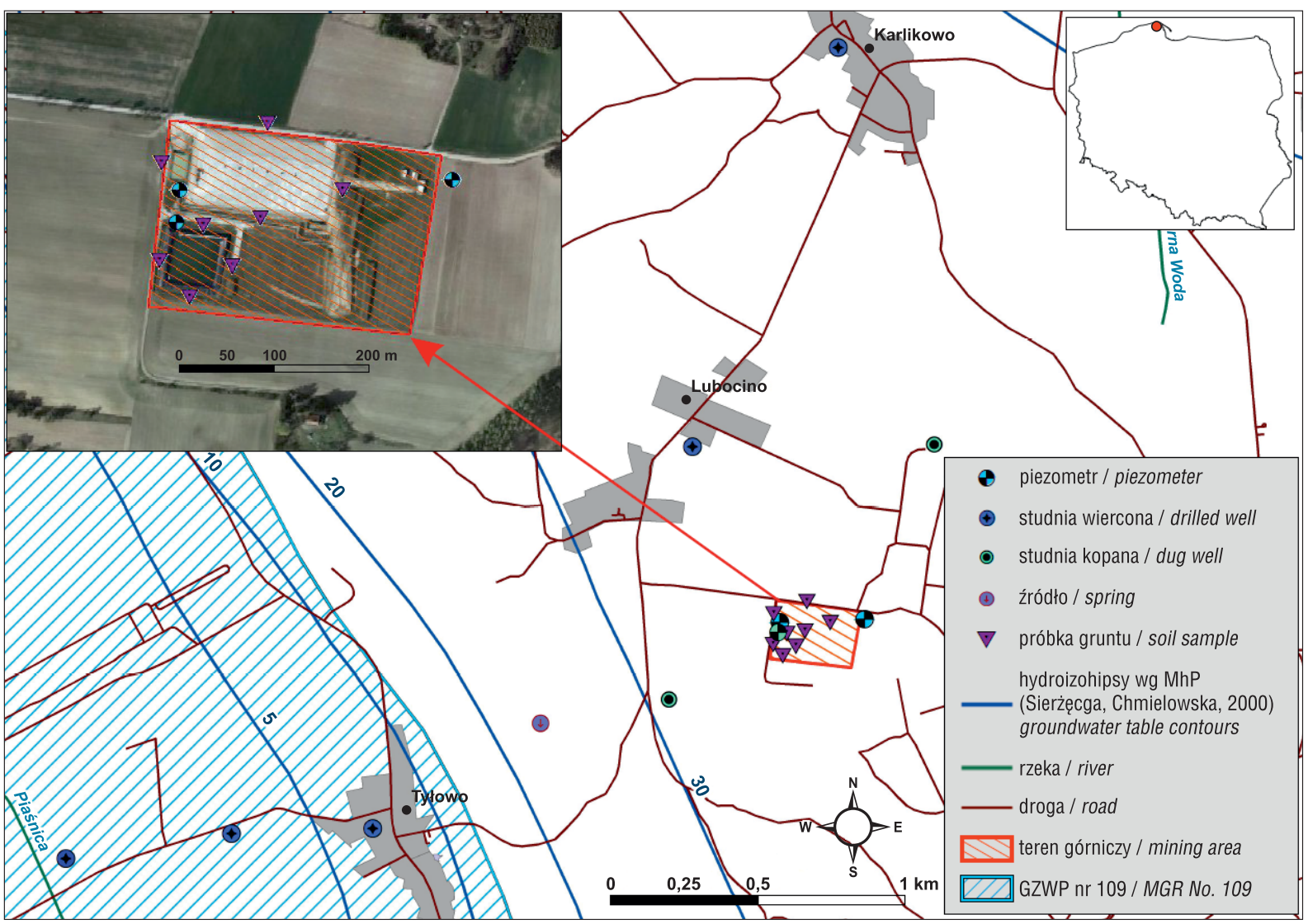

Ryc. 1. Lokalizacja punktów sieci monitoringu wód podziemnych w rejonie poszukiwania złóż weglowodorów

Fig. 1. Location of the points of groundwater monitoring network in the area of hydrocarbon exploration

na drodze przepływu wód podziemnych do Głównego Zbiornika Wód Podziemnych (GZWP) 109 (Dolina Kopalna Żarnowiec), oddalonego o ok. 2-4 km od placu wiertni (monitoring regionalny). Sieć składała się z 12 punktów: 3 piezometrów, 5 studni wierconych ujęć komunalnych oraz 2 gospodarskich studni kopanych i źródła (ryc. 1), a za jej pomoca prowadzono obserwację chemizmu wód podziemnych w 3 poziomach czwartorzędowych, pozostających ze sobą w więzi hydraulicznej.

W czasie 7 etapów badań monitoringowych wykonano 37 analiz fizykochemicznych wód podziemnych, które obejmowały 79 składników (właściwości fizykochemiczne, jony, substancje organiczne: WWA, B-TEX, indeks oleju mineralnego). W ramach badań monitoringowych analizowano również chemizm próbek gruntów pobieranych z otoczenia placu wiertni. Pobrano łącznie 82 próbki gruntu, w których zbadano zawartość 53 składników (metali, substancji organicznych WWA, B-TEX, indeks oleju mineralnego, benzyn). Wszystkie oznaczenia fizykochemiczne wód i gruntów przeprowadzono w akredytowanym laboratorium WESSLING Polska Sp. z o.o.

Oprócz rozszerzonego zakresu analiz chemicznych, dodatkową specyfiką tej sieci monitoringowej była częstotliwość badań, którą dostosowano do rzeczywistych etapów prowadzonej działalności (tab. 1).

\section{METODYKA}

Do oceny rzeczywistego oddziaływania monitorowanego obiektu na chemizm wód podziemnych zaproponowano wykorzystanie specjalnych wskaźników geochemicznych, które mogą dać odpowiedź na pytanie: czy obserwowane stężenia wybranych składników wód podziemnych świadczą o antropogenicznym zanieczyszczeniu oraz jaki jest stopień ewentualnego zanieczyszczenia. Do tego celu wykorzystano wskaźniki geochemiczne powszechnie stosowane do oceny antropogenicznego zanieczyszczenia gruntów i osadów, a także coraz częściej wykorzystywane w ocenie stanu chemicznego wód powierzchniowych (Selinus, Esbensen, 1995; Reimann, de Caritat, 2005; Cevik i in., 2009; Szalińska i in., 2010; Gałuszka, Migaszewski, 2011; Pandey i in., 2015; Barbieri, 2016; Hassaan i in., 2016; Bern i in., 2019). Ich zastosowanie opiera się na znajomości wartości tła geochemicznego poszczególnych składników chemicznych w danym środowisku. Proponowane do zastosowania dla wód podziemnych wskaźniki to: współczynnik wzbogacenia (Enrichment Factor - EF), współczynnik zanieczyszczenia (Contamination Factor - CF), wskaźnik ładunku zanieczyszczeń (Pollution Load Index - PLI), wskaźnik geoakumulacji (Geoaccumulation index $-I_{\text {geo }}$ )

Zakres tła hydrogeochemicznego dla wód czwartorzędowego piętra wodonośnego w rejonie badań obliczono na podstawie wyników analiz fizykochemicznych wód podziemnych z sieci monitoringowej z lat 2011-2018 (tab. 2). Zastosowano metodykę 16 i 84\%o (Kmiecik, Postawa, 2003). Wyniki analiz fizykochemicznych wód podziemnych oraz tła hydrogeochemicznego posłużyły następnie do obliczeń wskaźników geochemicznych antropopresji.

Współczynnik wzbogacenia (Enrichment Factor - EF) służy do oceny wpływu zanieczyszczeń antropogenicznych na koncentracje poszczególnych składników rozpu- 
Tab. 1. Etapy badań monitoringowych wód podziemnych w obszarze prowadzonych poszukiwań węglowodorów wraz z uwagami dotyczącymi przyczyn zagrożeń wód podziemnych

Table 1. Stages of groundwater monitoring in the area of hydrocarbon exploration along with comments on the causes of groundwater threats

\begin{tabular}{|c|c|c|}
\hline $\begin{array}{l}\text { Etap } \\
\text { Stage }\end{array}$ & $\begin{array}{l}\text { Dzialalność } \\
\text { Type of activity }\end{array}$ & $\begin{array}{l}\text { Możliwe przyczyny zagrożenia wód podziemnych. Uwagi } \\
\text { Possible causes of groundwater threats. Comments }\end{array}$ \\
\hline Etap 0 & $\begin{array}{l}\text { stan bazowy, } \\
\text { przed rozpoczęciem wierceń }\end{array}$ & $\begin{array}{l}\text { ocena stanu bazowego środowiska gruntowo-wodnego jest zalecaná praktyką w celu } \\
\text { identyfikacji zagrożeń dla jakości wód podziemnych na terenach górniczych; } \\
\text { rozpoczęcie inwestycji i przygotowanie placu wiertniczego zagrożenia dla wód } \\
\text { podziemnych wynikają z okresowego ryzyka skażenia terenu awaryjnymi wyciekami } \\
\text { paliw i płynów pracujących pojazdów i maszyn na drodze infiltracji zanieczyszczeń } \\
\text { z powierzchni terenu; jest to szczególnie istotny etap prac, gdyż prawidłowość } \\
\text { wykonanych zabezpieczeń warunkować będzie możliwość zanieczyszczenia wód } \\
\text { podziemnych także z przecieków z wadliwie skonstruowanych zbiorników, rowów } \\
\text { i infrastruktury na placu wiertni }\end{array}$ \\
\hline Etap 1 & $\begin{array}{l}\text { podczas i po odwierceniu } \\
\text { otworu pionowego }\end{array}$ & $\begin{array}{l}\text { podczas wykonywanych wierceń do zanieczyszczenia wód podziemnych może dojść } \\
\text { w wyniku m.in. przedostania się płuczki wiertniczej lub wód złożowych do poziomów } \\
\text { wodonośnych, kontaktu i mieszania się wód z różnych poziomów wodonośnych; } \\
\text { zanieczyszczenia wód podziemnych może wystapić wskutek zdarzeń nieprzewidzianych } \\
\text { (np. awaria urządzeń wiertniczych i związanych z nimi wycieku cieczy } \\
\text { technologicznych) }\end{array}$ \\
\hline Etap 2 & $\begin{array}{l}\text { przed realizacją szczelinowania } \\
\text { hydraulicznego }\end{array}$ & $\begin{array}{l}\text { etap II badań monitoringowych był traktowany jako stan bazowy dla oceny wpływu } \\
\text { szczelinowania hydraulicznego na wody podziemne }\end{array}$ \\
\hline Etap 3 & $\begin{array}{l}\text { podczas i po realizacji } \\
\text { szczelinowania }\end{array}$ & $\begin{array}{l}\text { w trakcie przeprowadzania zabiegów stymulacji złoża ryzyko zanieczyszczenia wód } \\
\text { podziemnych może być związane z niekontrolowaną migracją gazu, wód złożowych lub } \\
\text { płynów technologicznych wynikającą z nieprzewidzianej propagacji szczelin lub } \\
\text { udrożnienia lokalnych stref dyslokacyjnych (uskoków); potencjalne zanieczyszczenie } \\
\text { wód może wynikać z wadliwej konstrukcji odwiertu, przedostania się zanieczyszczeń } \\
\text { z powierzchni terenu, nieprzewidzianych zdarzeń (np. awarii urządzeń } \\
\text { i spowodowanego tym, niekontrolowanego wylania się płynów technologicznych) }\end{array}$ \\
\hline Etap 4 & $\begin{array}{l}\text { po odwierceniu otworu } \\
\text { horyzontalnego }\end{array}$ & $\begin{array}{l}\text { możliwe zanieczyszczenia wód podziemnych są podobne jak w przypadku wiercenia } \\
\text { otworu pionowego; możliwa jest także kumulacja oddziaływań wynikająca } \\
\text { z kilkuetapowej działalności górniczej }\end{array}$ \\
\hline Etap 5 & $\begin{array}{l}\text { po realizacji szczelinowania } \\
\text { hydraulicznego w otworze } \\
\text { horyzontalnym }\end{array}$ & $\begin{array}{l}\text { zagrożenia wód podziemnych jak w przypadku etapu III; kolejny zabieg szczelinowania } \\
\text { hydraulicznego można także traktować, w zakresie identyfikacji zagrożeń wód } \\
\text { podziemnych, jak etap eksploatacji; potencjalne zagrożenie wód podziemnych wynika } \\
\text { z możliwej migracji zanieczyszczeń do wód podziemnych wskutek uszkodzonej } \\
\text { infrastruktury, m.in. korozji rur okładzinowych, rozszczelnienie cementu, uszkodzenie } \\
\text { lub zniszczenie zabezpieczeń na powierzchni terenu }\end{array}$ \\
\hline Etap 6 & po rekonstrukcji placu wiertni & $\begin{array}{l}\text { po zakończeniu poszukiwań lub eksploatacji konieczna jest likwidacja otworu oraz } \\
\text { rekultywacji terenu; celem jest przywrócenie pierwotnej funkcji terenu oraz w miarę } \\
\text { możliwości odtworzenie jego naturalnych walorów; zagrożenie wód podziemnych jest } \\
\text { możliwe podczas prowadzonych prac rekonstrukcyjnych }\end{array}$ \\
\hline Etap 7 & $\begin{array}{l}\text { po likwidacji odwiertów i placu } \\
\text { wiertni }\end{array}$ & $\begin{array}{l}\text { podczas etapu likwidacji placu wiertni i otworów w wyniku nieprawidłowo } \\
\text { przeprowadzanych prac może dojść do emisji gazu złożowego i migracji ropy naftowej } \\
\text { i zanieczyszczenia nimi wód podziemnych (Everett, 1985) }\end{array}$ \\
\hline
\end{tabular}

szczonych w wodach podziemnych. Do obliczeń jego wartości służy wzór [1]:

$$
E F=\frac{\left[C_{x} / C_{r e f}\right]_{p r o b k a}}{\left[C_{x} / C r_{e f}\right]_{t \nmid o}}
$$

gdzie:

$C_{x}-$ stężenie badanego składnika $\left(\mathrm{mg} / \mathrm{dm}^{3}\right)$,

$C_{r e f}$ - stężenie składnika odniesienia - dla próbki wody podziemnej (próbka) oraz dla wartości tła hydrogeochemicznego (tło) (mg/dm³ ) (Barbieri, 2016; Bern i in., 2019).

Zakłada się, że jeśli wartość $E F \leq 1$, to znaczy, że badany składnik pochodzi ze źródeł geogenicznych, składniki o wartości EF $>1$ mają pochodzenie antropogeniczne (Szalińska i in., 2010; Pandey i in., 2015).

Czynnikiem normalizującym musi być obecny w wodzie tzw. składnik odniesienia (składnik referencyjny $-C_{r e f}$ ), który cechuje się tym, że nie ma znaczących źródeł pochodzenia antropogenicznego, jest składnikiem konserwatywnym, czyli dobrze migruje w wodzie, nie biorąc znacznego udziału w cyklu biogeochemicznym. Do najczęściej wykorzystywanych w tej roli do badań gruntów i osadów należą takie pierwiastki jak: Si, Al, Fe, Sc, Cs, Li (Gałuszka, Migaszewski, 2011).
Współczynnik zanieczyszczenia (Contamination Factor - $C F$ ) odnosi średnie stężenie danego składnika do wartości tła hydrogeochemicznego tego składnika, wg wzoru [2]:

$$
C F=\frac{\left[C_{x}\right]_{\text {próbka }}}{\left[C_{x}\right]_{t \nmid o}}
$$

gdzie:

$\left[C_{x}\right]_{\text {próbka }}$ - średnie stężenie składnika w próbkach wody podziemnej $\left(\mathrm{mg} / \mathrm{dm}^{3}\right)$,

$\left[C_{x}\right]_{\text {tlo }}$ - wartość tła hydrogeochemicznego dla składnika $\left(\mathrm{mg} / \mathrm{dm}^{3}\right)$.

Stopień zanieczyszczenia rośnie wraz ze wzrostem wartości $C F$ :

a) $<1$ brak zanieczyszczenia,

b) 1-2 - bardzo niski,

c) 2-3-niski,

d) 3-4 - średni,

e) 4-5 - znaczny,

f) 5-6- silny,

g) >6 bardzo silny (Pandey $\mathrm{i}$ in., 2015; Bern $\mathrm{i}$ in., 2019).

Wskaźnik geoakumulacji (Geoaccumulation Index $I_{\text {geo }}$ ) obliczone zgodnie ze wzorem [3]: 


\begin{tabular}{|c|c|c|c|c|c|c|c|c|c|c|c|c|c|c|c|c|c|c|}
\hline 焉 & $\begin{array}{l}\tilde{\Xi} \\
\stackrel{0}{\circ}\end{array}$ & $\stackrel{\bar{n}}{r}$ & $\begin{array}{l}\tilde{n} \\
\hat{n} \\
0\end{array}$ & $\frac{2}{0}$ & 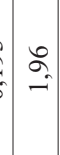 & Oे & $=$ & 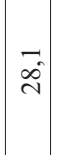 & $\begin{array}{c}\text { yे } \\
\text { s. } \\
0\end{array}$ & 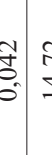 & 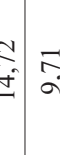 & $\begin{array}{c}n \\
\hat{n} \\
0 \\
0\end{array}$ & $\begin{array}{l}\hat{0} \\
: \\
0\end{array}$ & 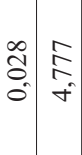 & $\frac{g}{q}$ & 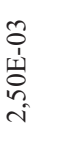 & $\mid \begin{array}{l}0 \\
0 \\
1 \\
1 \\
1 \\
0 \\
m \\
n \\
n\end{array}$ & $\frac{a}{0}$ \\
\hline 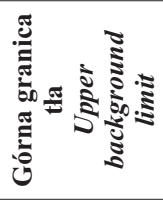 & $\begin{array}{l}\tilde{n} \\
\stackrel{-}{i}\end{array}$ & $\stackrel{2}{\circ}$ & $\begin{array}{l}\text { gे } \\
\text { ì } \\
i n\end{array}$ & $\begin{array}{l}0 \\
3 \\
0 \\
0\end{array}$ & $\begin{array}{l}\vec{\sigma} \\
m\end{array}$ & 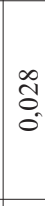 & 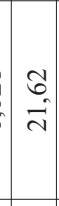 & 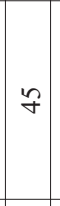 & $\begin{array}{ll} \pm & \\
\infty & \\
n & \\
0 & \end{array}$ & 草 & 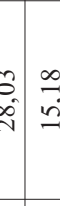 & $\begin{array}{l}7 \\
\stackrel{f}{0}\end{array}$ & $\begin{array}{l}\stackrel{ \pm}{\beth} \\
0\end{array}$ & $\begin{array}{cc}\vec{s} & \vec{n} \\
0 & \end{array}$ & : & 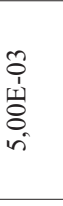 & 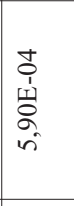 & 苂 \\
\hline 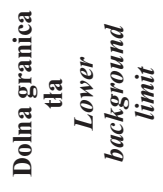 & $\begin{array}{l}\infty \\
\stackrel{\infty}{\sim} \\
\sim\end{array}$ & i & 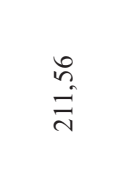 & $\stackrel{8}{\circ}$ & {$\left[\begin{array}{l} \pm \\
n \\
0\end{array}\right.$} & $\stackrel{0}{\circ}$ & $\begin{array}{l}0 \\
0 \\
0\end{array}$ & $\stackrel{\cong}{=}$ & $\overrightarrow{0}$ & $\begin{array}{l}0 \\
0 \\
0\end{array}$ & $\stackrel{f}{I} \underset{f}{\stackrel{J}{J}}$ & 吕 & $\begin{array}{l}\stackrel{0}{\circ} \\
: \\
\circ\end{array}$ & 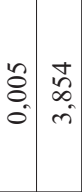 & $\left|\begin{array}{l}\vec{\infty} \\
0 \\
0 \\
0\end{array}\right|$ & 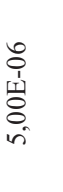 & $\begin{array}{l}n \\
0 \\
1 \\
1 \\
\vdots \\
0 \\
\infty \\
\infty\end{array}$ & $\begin{array}{l}\tilde{0} \\
0\end{array}$ \\
\hline ثี & $\hat{n}$ & m & $\tilde{m}$ & m & $\approx$ & लै & $\tilde{m}$ & m & 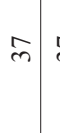 & $m$ & $m$ & m & $\bar{m}$ & $\tilde{m} \cong$ & $\simeq$ & లె & $\hat{m}$ & m \\
\hline$\frac{\dot{s}}{\dot{m}}$ & $\begin{array}{l}n \\
n \\
n\end{array}$ & के & $\stackrel{\text { In }}{=}$ & $\stackrel{3}{3}$ & 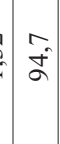 & $\begin{array}{l}\bar{\alpha} \\
\alpha_{0} \\
\sigma^{\prime}\end{array}$ & 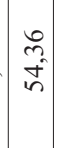 & $\hat{\imath}$ & 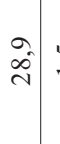 & $\because$ & 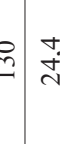 & 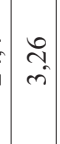 & $\stackrel{0}{\cong}$ & \begin{tabular}{c|c}
$\mathbb{1}$ \\
$i$ \\
$i$
\end{tabular} & \begin{tabular}{|l}
$\bar{n}$ \\
$n$ \\
0
\end{tabular} & $\begin{array}{l}\stackrel{0}{\circ} \\
\stackrel{0}{0}\end{array}$ & 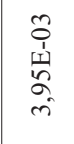 & $\begin{array}{l}\infty \\
\infty \\
0 \\
0\end{array}$ \\
\hline$\dot{\dot{\Xi}}$ & $\stackrel{\vec{f}}{ }$ & $\stackrel{0}{0}$ & $\stackrel{\infty}{\infty}$ & $\stackrel{\circ}{\circ}$ & $\begin{array}{l}\overline{0} \\
0\end{array}$ & $\stackrel{0}{0}$ & $\mid \begin{array}{l}n \\
\infty \\
-1\end{array}$ & $\overrightarrow{0}$ & $\overrightarrow{0}$ & 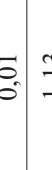 & $=\infty$ & 足 & $\begin{array}{l}0 \\
\vdots \\
0 \\
0\end{array}$ & 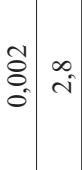 & {$\left[\begin{array}{l}\infty \\
0 \\
0 \\
0\end{array}\right.$} & $\begin{array}{l}8 \\
\stackrel{1}{1} \\
\text { 11 } \\
0 \\
\text { in }\end{array}$ & 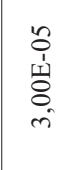 & $\tilde{D}_{0}$ \\
\hline 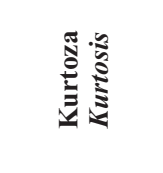 & $\begin{array}{l}\overline{0} \\
\dot{9}\end{array}$ & ते & $\begin{array}{c}n \\
\text { in }\end{array}$ & 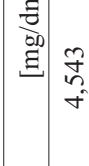 & 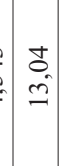 & $\begin{array}{l}q \\
q \\
\infty \\
i d\end{array}$ & $\underline{i}$ & $\begin{array}{c}\bar{\sigma} \\
\text { o. }\end{array}$ & $\begin{array}{l}\infty \\
\infty \\
0 \\
-1\end{array}$ & 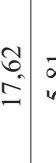 & 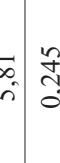 & $\begin{array}{l}\tilde{3} \\
\tilde{0} \\
0\end{array}$ & $\begin{array}{l}\stackrel{+}{*} \\
\stackrel{m}{m}\end{array}$ & 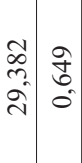 & $\begin{array}{l}\overline{\tilde{\sigma}} \\
\hat{i}\end{array}$ & 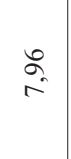 & $\underset{\infty}{\infty}$ & 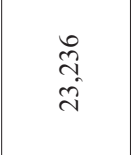 \\
\hline 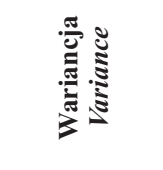 & $\vec{a}$ & $\underset{-}{J}$ & $\begin{array}{l}\hat{q} \\
\stackrel{\Delta}{\circ} \\
\text { ñ } \\
\vec{n}\end{array}$ & $\stackrel{2}{\circ}$ & $\begin{array}{c}\mid \\
\dot{z} \\
\tilde{y} \\
\bar{z}\end{array}$ & ¿̂े & : & $\begin{array}{c}n \\
2 \\
0 \\
0\end{array}$ & \begin{tabular}{l|l}
$\hat{0}$ \\
0 \\
0 \\
0 \\
$c$
\end{tabular} & 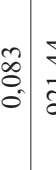 & 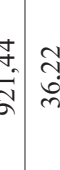 & $\begin{array}{l}2 \\
\vdots \\
0 \\
0\end{array}$ & $\begin{array}{l} \pm \\
\dot{a} \\
0 \\
0\end{array}$ & 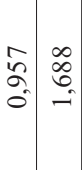 & 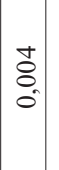 & 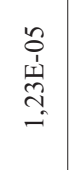 & 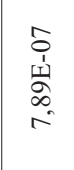 & $\begin{array}{l}\stackrel{2}{2} \\
\stackrel{0}{0}\end{array}$ \\
\hline 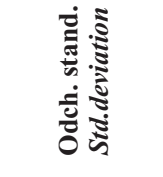 & $\begin{array}{l}\vec{\infty} \\
\vec{i}\end{array}$ & $\stackrel{\cong}{\Im}$ & 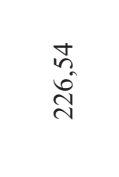 & 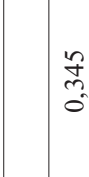 & 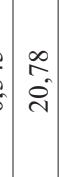 & $\begin{array}{l}\infty \\
\stackrel{2}{0} \\
0\end{array}$ & $\begin{array}{l}\bar{a} \\
\hat{\jmath}\end{array}$ & $\begin{array}{c}\tilde{f} \\
\stackrel{f}{\Xi}\end{array}$ & $\begin{array}{l}\tilde{A} \\
n \\
n \\
n\end{array}$ & 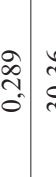 & $\begin{array}{l}0 \\
: \\
m \\
m \\
m\end{array}$ & {$\left[\begin{array}{l}n \\
\vdots \\
0 \\
0\end{array}\right.$} & 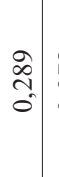 & 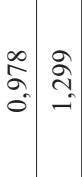 & $\left|\begin{array}{l}n \\
0 \\
0 \\
0\end{array}\right|$ & $\begin{array}{l}m \\
0 \\
1 \\
1 \\
n \\
m \\
m\end{array}$ & 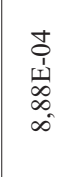 & $\frac{n}{0}$ \\
\hline 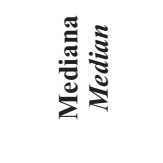 & $\stackrel{\circ}{\simeq}$ & \begin{tabular}{l}
$\infty$ \\
\hdashline \\
$i$
\end{tabular} & f & $\stackrel{2}{\circ}$ & $\because$ & : & $\mid \begin{array}{l}n \\
2 \\
0 \\
0\end{array}$ & $\overrightarrow{\hat{i}}$ & $\overrightarrow{0}$ & 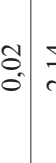 & 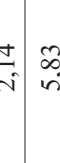 & 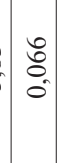 & $\begin{array}{l}\overline{\tilde{r}} \\
\tilde{0}\end{array}$ & 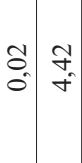 & $\mid \begin{array}{c}\overline{\mathrm{I}} \\
0\end{array}$ & $\begin{array}{l}\underset{0}{0} \\
\stackrel{1}{d} \\
0 \\
- \\
-1\end{array}$ & $\begin{array}{l}n \\
0 \\
\text { ज. } \\
0 \\
0 \\
\infty\end{array}$ & $\tilde{0}_{0}$ \\
\hline 营 & $\begin{array}{l}\Delta \\
\stackrel{0}{0}\end{array}$ & ले & $\begin{array}{l}\stackrel{2}{\circ} \\
\stackrel{7}{\sigma}\end{array}$ & $\begin{array}{l}\text { तี } \\
\text { Oे }\end{array}$ & $\stackrel{f}{\therefore}$ & $\begin{array}{l}\bar{n} \\
\dot{0}\end{array}$ & $\begin{array}{l}\hat{\infty} \\
\dot{f} \\
\dot{f}\end{array}$ & $\left|\begin{array}{c}1 \\
\vdots \\
i \\
i\end{array}\right|$ & \begin{tabular}{c}
0 \\
1 \\
0 \\
\hdashline \\
-
\end{tabular} & $\begin{array}{l}0 \\
0 \\
0\end{array}$ & 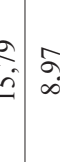 & $\begin{array}{c}0 \\
2 \\
\vdots \\
0 \\
0\end{array}$ & $\begin{array}{l}\infty \\
\stackrel{0}{0} \\
0\end{array}$ & 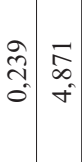 & $\frac{ \pm}{0}$ & $\begin{array}{l}0 \\
\hat{1} \\
1 \\
0 \\
0 \\
-1\end{array}$ & 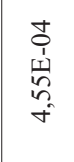 & $\begin{array}{l}\tilde{\delta} \\
0 \\
0\end{array}$ \\
\hline 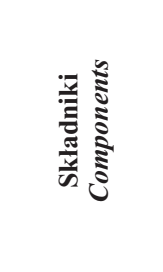 & 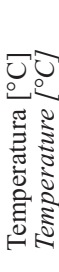 & T & 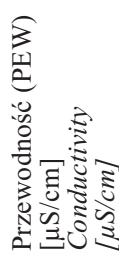 & z & 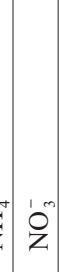 & & $\bar{U}$ & {$\left[\begin{array}{l}0 \\
0 \\
\infty\end{array}\right.$} & 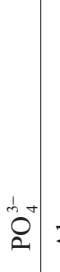 & $\varangle$ & 4 & 素 & $\stackrel{s}{s}$ & $\bar{N}: \vec{s}$ & $\dot{n}$ & 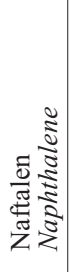 & 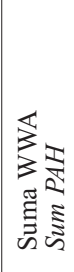 & 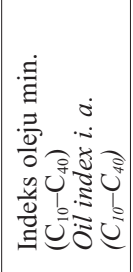 \\
\hline
\end{tabular}


Tab. 3. Wartości współczynnika wzbogacenia $E F$ przy zastosowaniu różnych składników referencyjnych $C_{\text {ref }}(\mathrm{Al}, \mathrm{Si}, \mathrm{Sr})$

Table 3. $E F$ enrichment factor values using various reference ingredients $C_{r e f}(\mathrm{Al}, \mathrm{Si}, \mathrm{Sr})$

\begin{tabular}{|c|c|c|c|}
\hline \multirow{2}{*}{$\begin{array}{l}\text { Skladniki } \\
\text { Components }\end{array}$} & \multicolumn{3}{|c|}{$\begin{array}{c}\text { Wartość wspólczynnika wzbogacenia } E F \\
\text { EF enrichment factor values }\end{array}$} \\
\hline & $C_{r e f} \mathrm{Al}$ & $C_{r e f} \mathrm{Si}$ & $C_{r e f} \mathrm{Sr}$ \\
\hline $\mathrm{Cl}^{-}$ & 0,43 & 1,03 & 1,12 \\
\hline $\mathrm{SO}_{4}^{2-}$ & 0,43 & 1,03 & 1,12 \\
\hline $\mathrm{PO}_{4}^{3-}$ & 2,16 & 5,23 & 5,68 \\
\hline $\mathrm{NO}_{3}^{-}$ & 1,54 & 3,73 & 4,05 \\
\hline $\mathrm{NO}_{2}^{2-}$ & 1,07 & 2,60 & 2,82 \\
\hline $\mathrm{NH}^{4+}$ & 0,45 & 1,08 & 1,17 \\
\hline $\mathrm{K}^{+}$ & 0,43 & 1,05 & 1,14 \\
\hline $\mathrm{Na}^{+}$ & 0,37 & 0,91 & 0,98 \\
\hline $\mathrm{Fe}^{2 / 3+}$ & 0,41 & 0,98 & 1,07 \\
\hline $\mathrm{Mn}^{2 / 3+}$ & 0,64 & 1,55 & 1,68 \\
\hline $\mathrm{Zn}^{+}$ & 3,47 & 8,40 & 9,11 \\
\hline $\begin{array}{l}\text { Naftalen } \\
\text { Naphthalene }\end{array}$ & 0,30 & 0,73 & 0,79 \\
\hline $\begin{array}{l}\text { Suma WWA } \\
\text { Sum PAH }\end{array}$ & 0,55 & 1,33 & 1,45 \\
\hline $\begin{array}{l}\text { Indeks oleju mine- } \\
\text { ralnego }\left(\mathrm{C}_{10}-\mathrm{C}_{40}\right) \\
\text { Oil index } i . a . \\
\left(C_{10}-C_{40}\right)\end{array}$ & 1,24 & 3,02 & 3,27 \\
\hline
\end{tabular}

$$
\begin{aligned}
E F>1 & \\
I_{\text {geo }} & =\log _{2} \frac{\left[C_{x}\right]_{\text {probka }}}{1,5 \cdot\left[C_{x}\right]_{t \nmid o}}
\end{aligned}
$$

gdzie:

$\left[C_{x}\right]_{\text {próbka }}$ - średnie stężenie składnika w próbkach wody podziemnej $\left(\mathrm{mg} / \mathrm{dm}^{3}\right)$,

$\left[C_{x}\right]_{t l o}$ - wartość tła hydrogeochemicznego dla składnika $\left(\mathrm{mg} / \mathrm{dm}^{3}\right)$.

Wartość wskaźnika $I_{g e o}<0$ świadczy o braku zanieczyszczenia, natomiast zakres $0-1$ to małe zanieczyszczenie, 1-2 - umiarkowane zanieczyszczenie, 2-3 - średnie zanieczyszczenie, 3-4 - znaczące zanieczyszczenie, 4-5 silne zanieczyszczenie, $>5$ - ekstremalne zanieczyszczenie (Guimaraes i in., 2011; Barbieri, 2016; Bahloul i in., 2018).

Wskaźnik ładunku zanieczyszczeń PLI (Pollution Load Index), wg wzoru [4]:

$$
P L I=\sqrt[n]{C_{F 1} \cdot C_{F 2} \cdot \ldots \cdot C_{F n}}
$$

gdzie:

$C_{F 1}$ - iloraz stężenia danego składnika w próbce wód podziemnych i wartości jego tła hydrogeochemicznego $\left(\mathrm{mg} / \mathrm{dm}^{3}\right)$,

$C_{F n}$ - iloraz stężenia $n$-tego składnika w próbce wód podziemnych i wartości jego tha hydrogeochemicznego $\left(\mathrm{mg} / \mathrm{dm}^{3}\right)$.

Przyjmuje się, że wartości $P L I<1$ świadczą o braku zanieczyszczenia, a $P L I>1$ o występowaniu zanieczyszczenia (Gałuszka, Migaszewski, 2011; Pandey i in., 2015).

\section{DYSKUSJA WYNIKÓW}

Do celów tej pracy wyznaczono wartości tła hydrogeochemicznego oraz charakterystycznych parametrów sta-
Tab. 4. Wartości wskaźników geoakumulacji $I_{g e o}$, ładunku zanieczyszczeń $P L I$ oraz współczynnika zanieczyszczenia $C F$

\begin{tabular}{|c|c|c|c|}
\hline $\begin{array}{c}\text { Skladniki } \\
\text { Components }\end{array}$ & $C F$ & $I_{g e o}$ & PLI \\
\hline $\mathrm{Cl}^{-}$ & 1,05 & $-0,51$ & 0,40 \\
\hline $\mathrm{SO}_{4}^{2-}$ & 1,05 & $-0,51$ & 0,70 \\
\hline $\mathrm{PO}_{4}^{3-}$ & 5,34 & 1,83 & 0,62 \\
\hline $\mathrm{NO}_{3}^{-}$ & 3,81 & 1,34 & 0,69 \\
\hline $\mathrm{NO}_{2}^{2-}$ & 2,65 & 0,82 & 0,92 \\
\hline $\mathrm{NH}^{4+}$ & 1,10 & $-0,45$ & 0,41 \\
\hline $\mathrm{K}^{+}$ & 1,07 & $-0,48$ & 0,31 \\
\hline $\mathrm{Na}^{+}$ & 0,92 & $-0,70$ & 0,76 \\
\hline $\mathrm{Fe}^{2 / 3+}$ & 1,00 & $-0,76$ & 0,20 \\
\hline $\mathrm{Mn}^{2 / 3+}$ & 1,58 & 0,07 & 0,54 \\
\hline $\mathrm{Zn}^{+}$ & 8,57 & 2,51 & 0,92 \\
\hline $\begin{array}{l}\text { Naftalen } \\
\text { Naphthalene }\end{array}$ & 0,74 & $-1,02$ & 0,06 \\
\hline $\begin{array}{l}\text { Suma WWA } \\
\text { Sum PAH }\end{array}$ & 1,36 & $-0,14$ & 0,45 \\
\hline $\begin{array}{l}\text { Indeks oleju mine- } \\
\text { ralnego }\left(\mathrm{C}_{10}-\mathrm{C}_{40}\right) \\
\text { Oil index } i . a \text {. } \\
\left(C_{10}-C_{40}\right)\end{array}$ & 3,08 & 1,04 & 0,96 \\
\hline
\end{tabular}

Table 4. Values of $I_{g e o}$ geoaccumulation indicators, $P L I$ pollution load and $C F$ pollution coefficient

$$
C F>3 ; I_{\text {geo }}>1 ; P L I \approx 1
$$

tystycznych wyłącznie dla wybranych składników wód podziemnych piętra czwartorzędowego. Zdecydowano się zaprezentować składniki uważane za wskaźniki zanieczyszczeń wód podziemnych:

- wskaźniki charakterystyczne dla działalności prowadzonej na monitorowanym obiekcie (substancje organiczne: WWA, naftalen, indeks oleju mineralnego),

- wskaźniki typowe dla rodzaju zagospodarowania otoczenia obiektu - pochodzenia rolniczego (azotany, fosforany, potas, sód, chlorki, siarczany, jon amonowy) (tab. 2). Oprócz tego w tabeli tej umieszczono również dane o substancjach wykorzystanych do obliczeń współczynnika wzbogacenia $E F$, a także najważniejsze właściwości fizykochemiczne ogólnie charakteryzujące badane wody podziemne.

Do oceny stopnia zanieczyszczenia antropogenicznego wód podziemnych w rejonie złóż węglowodorów zastosowano współczynnik wzbogacenia $E F$ (tab. 2). Z uwagi na bardzo ograniczoną literaturę tematu, wstępnie wykonano obliczenia dla trzech różnych składników referencyjnych $C_{r e f}: \mathrm{Si}, \mathrm{Al}$ i Sr. W tabeli 3 na szaro zaznaczono wartości $E F>1$ wskazujące na antropogeniczne pochodzenie wyróżnionych składników.

Zauważyć można znaczące rozbieżności w wynikach, zależnie od zastosowanego składnika referencyjnego $C_{r e f}$. Najmniejsze wartości współczynnika wzbogacenia $E F$ uzyskano przy normalizacji względem glinu (Al), największe wartości zostały osiagnięte przy zastosowaniu strontu (Sr), czego rezultatem jest również wskazanie na pochodzenie antropogeniczne aż 12 z 14 składników. Za najbardziej miarodajny składnik referencyjny uznano zatem glin (Al), ze względu na zgodność $\mathrm{z}$ wynikami obliczeń pozostałych indeksów geochemicznych, które zestawiono w tabeli 4 i na rycinie 2. Wyniki współczynnika wzbogacenia $E F$ sugerują, że wyraźne pochodzenie antropogeniczne w ba- 


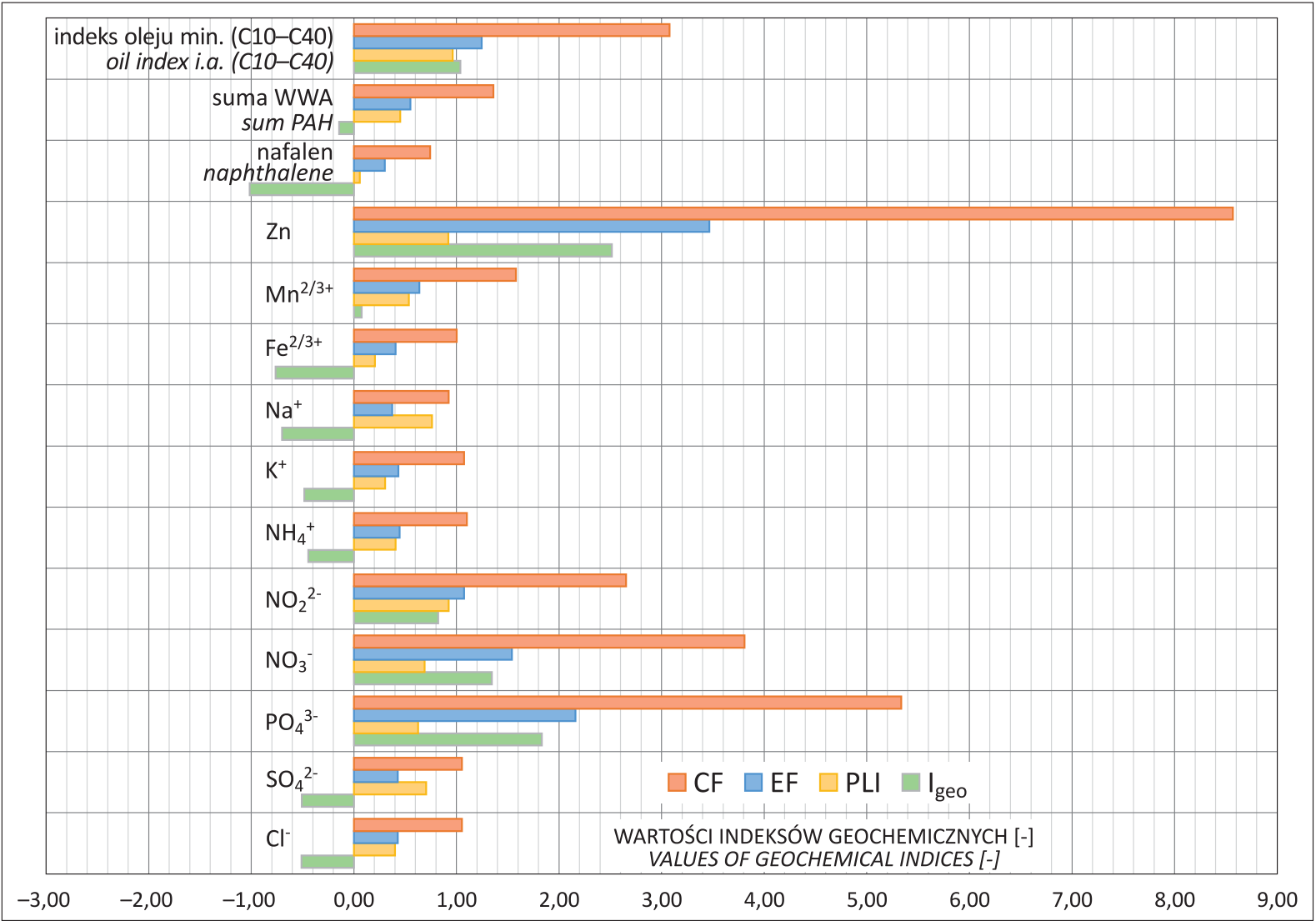

Ryc. 2. Wartości indeksów geochemicznych dla wód podziemnych rejonu badań

Fig. 2. Values of geochemical indexes for groundwater of the study area
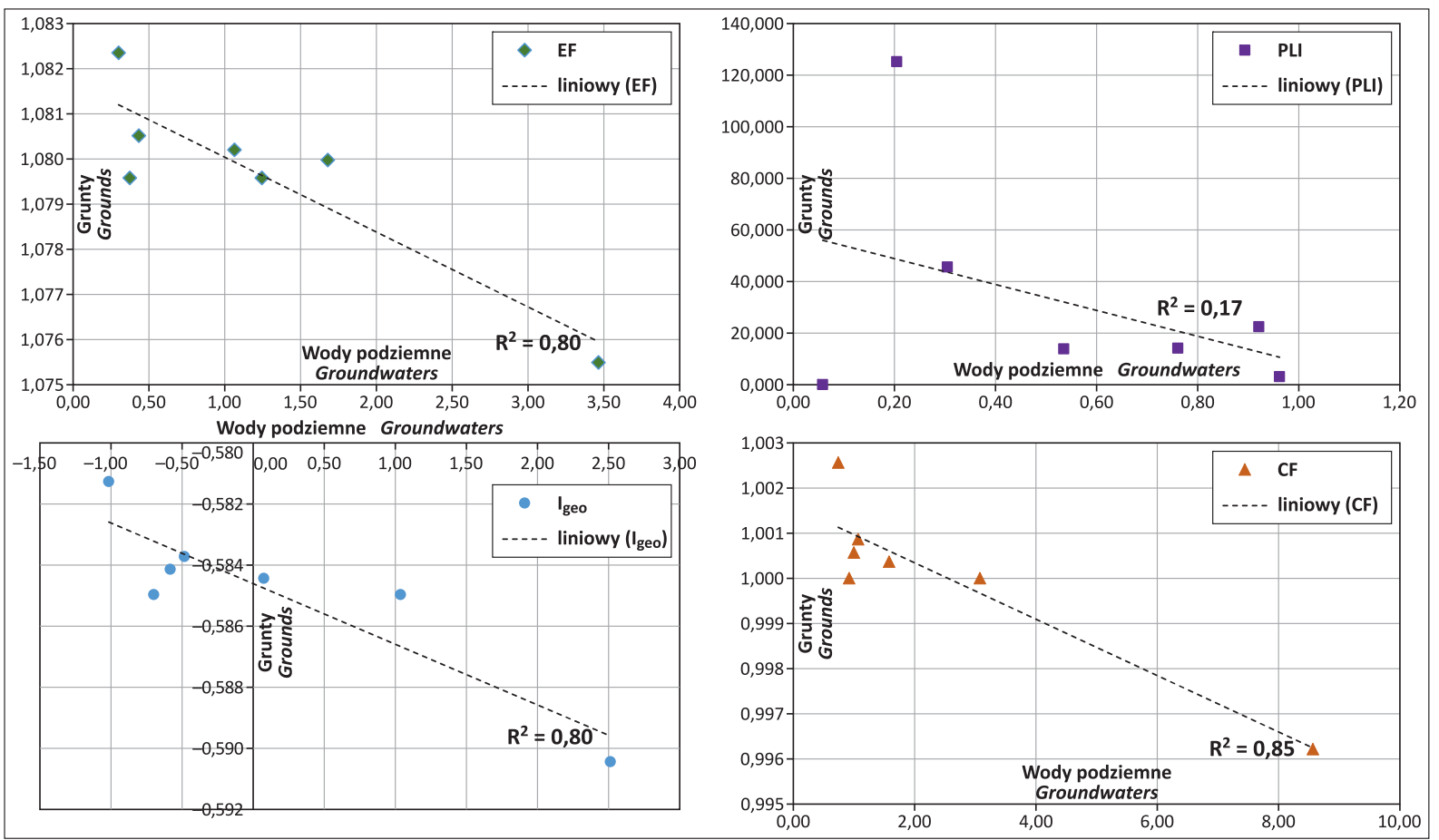

Ryc. 3. Korelacja wartości wskaźników geochemicznych $\left(P L I, I_{\text {geo }}, E F\right.$ i $\left.C F\right)$ w wodach podziemnych i gruntach

Fig. 3. Correlation of geochemical index values $\left(P L I, I_{g e o}, E F\right.$ and $\left.C F\right)$ in groundwaters and soils

danych wodach mają tylko: fosforany, azotany, azotyny, cynk i indeks oleju mineralnego.

Dla wód podziemnych piętra czwartorzędowego wartości współczynnika zanieczyszczenia $C F$ (tab. 4, ryc. 2) osiagają stopień świadczący o znaczącym zanieczyszczeniu $(C F>3)$ dla: azotanów, azotynów, fosforanów, cynku i indeksu oleju mineralnego, czyli dokładnie pokrywają się z wynikami współczynnika wzbogacenia $E F$ obliczonymi 
dla glinu (Al) jako składnika referencyjnego. Należy zwrócić uwagę, że w przypadku fosforanów stopień zanieczyszczenia oceniono na silny, zaś dla cynku na bardzo silny.

Analogiczną zależność zaobserwowano w przypadku wyników wskaźnika geoakumulacji $I_{\text {geo }}$. W próbkach wody podziemnej wartości $I_{g e o}>1$, a więc świadczące o występowaniu jednoznacznego zanieczyszczenia, stwierdzono dla azotanów, azotynów, fosforanów, cynku i indeksu oleju mineralnego (tab. 3, ryc. 2). Przy czym stopień zanieczyszczenia cynkiem określono na średni, azotanów, fosforanów i indeksu oleju mineralnego na umiarkowany, a azotynów na niski.

Dla badanych wód podziemnych wskaźnik ładunku zanieczyszczeń $P L I$ jest najbardziej zbliżony do 1 jedynie dla azotynów, cynku i indeksu oleju mineralnego (tab. 4, ryc. 2), co może świadczyć o tym, że ładunek zanieczyszczeń wszystkich omawianych wskaźników zanieczyszczeń jest stosunkowo nieduży.

Stosując taką samą metodykę jak w przypadku wód podziemnych, obliczono tło geochemiczne oraz wartości wskaźników geochemicznych dla gruntów w rejonie monitorowanego obiektu. Zakres badań chemicznych gruntów i wód podziemnych nie był w pełni zgodny, np. nie badano stężeń jonów w gruntach, zatem możliwe było sprawdzenie korelacji między wartościami wskaźnik ${ }^{\mathrm{o}} \mathrm{w}$ geochemicznych wód podziemnych i gruntów jedynie na podstawie pozostałych składników: sodu, potasu, żelaza, manganu, cynku, naftalenu i sumy WWA (ryc. 3).

Współczynnik korelacji liniowej, pomimo analizy przeprowadzonej na małej próbie statystycznej, wskazuje na występowanie silnej relacji między wartościami trzech wskaźników geochemicznych obliczonych dla wód i gruntów: współczynnika wzbogacenia $E F$ ( $\mathrm{R}^{2}$ wynosi 0,80$)$, wskaźnika zanieczyszczenia $C F\left(\mathrm{R}^{2}=0,85\right)$ oraz wskaźnika geoakumulacji $I_{g e o}\left(\mathrm{R}^{2}=0,80\right)$. Nie stwierdzono korelacji wartości wskaźnika ładunku zanieczyszczeń PLI między wodami podziemnymi a gruntami $\left(\mathrm{R}^{2}=0,17\right)$.

\section{PODSUMOWANIE}

Wieloetapowy, dedykowany monitoring wód podziemnych w rejonie poszukiwania i eksploatacji złóż węglowodorów wykazał, że wody z piętra czwartorzędowego cechują się dobrą jakością, a jedynie sporadycznie zanotowano przekroczenia dopuszczalnych w Rozporządzeniu Ministra Zdrowia z dnia 7 grudnia 2017 r. w sprawie jakości wody przeznaczonej do spożycia przez ludzi (Rozporządzenie, 2017) stężeń żelaza, manganu, potasu i niektórych substancji z grupy WWA. Należy podkreślić, że w kolejnych etapach badań monitoringowych nie stwierdzono występowania bezpośrednich przesłanek świadczących o wpływie działalności górniczej na wody podziemne. Wartości wskaźników $E F, C F, I_{\text {geo }}$ i $P L I$ wskazują na wpływ antropopresji na wody podziemne w zakresie fosforanów i cynku oraz oddziaływanie skutkujące wzrostem stężeń azotanów, azotynów i zwiększonego indeksu oleju mineralnego. Należy zauważyć, że pochodzenie azotanów, azotynów i fosforanów w wodach podziemnych można wiązać bezpośrednio z działalnością rolniczą prowadzoną na badanym terenie, podobnie jak wyższe wartości indeksu oleju mineralnego, które mogą być efektem mechanizacji rolnictwa.

Wykorzystanie wskaźników geochemicznych do oceny antropogenicznych zmian chemizmu wód podziemnych jest uzasadnione, co potwierdza silna korelacja między wartościami większości wskaźników wyznaczonymi dla wód podziemnych oraz gruntów. Metodyka oceny stopnia antropopresji wód podziemnych poprzez konkretne współczynniki i wskaźniki wymaga jednak dalszych badań i testów na dużych populacjach danych hydrogeochemicznych, szczególnie dla obszarów o stwierdzonym oddziaływaniu działalności człowieka na wody podziemne.

\section{LITERATURA}

BAHLOUL M., BAATI H., AMDOUNI R., AZRI CH. 2018 Assessment of heavy metals contamination and their potential toxicity in the surface sediments of Sfax Solar Saltern, Tunisia. Environ. Earth Sci., 77 (1): 27; doi: 10.1007/s12665-018-7227-7

BARBIERI M. 2016 - The Importance of Enrichment Factor (EF) and Geoaccumulation Index (Igeo) to Evaluate the Soil Contamination. J. Geol. Geophys., 5 (1): 1-4.

BERN C.R., WALTON-DAY K., NAFTZ D.L. 2019 - Improved enrichment factor calculations through principal component analysis: Examples from soils near breccia pipe uranium mines, Arizona, USA. Environ. Pollut., 248: 90-100.

CEVIK F., GEOKSU M.Z.L., DERICI O.B., FINDIK E.O. 2009 - An assessment of metal pollution in surface sediments of Seyhan dam by using enrichment factor, geoaccumulation index and statistical analyses. Environ. Monit. Assess., 152: 309-317.

EVERETT L.G. 1985 - Developments in Water Science, Volume 24: Groundwater Monitoring Handbook for Coal and Oil Shale Development. Elsevier, New York: 304.

GAŁUSZKA A., MIGASZEWSKI Z. 2011 - Geochemical backgroundan environmental perspective. Mineralogia, 42 (1): 7-17.

GUIMARAES G.M.,FRANKLIN R.L., FIGUEIREDO A.M.G., SILVAP.SC., FAVARO D.I.T. 2011 - Enrichment factor and geoaccumulation index applied to sediment samples from Guarapiranga Reservoir, Brazil, Bor metal and trace element assessment. Associacao Brasileria De Eneria Nuclear - ABEN

HASSAAN M.A., NEMR A.E., MADKOUR F.F. 2016 - Environmental Assessment of Heavy Metal Pollution and Human Health Risk. Amer. J. Water Sci. Eng., 2 (3): 14-19.

KMIECIK E., POSTAWA A. 2003 - Wybrane aspekty metodyczne wyznaczania tła hydrogeochemicznego. Współczesne Problemy Hydrogeologii, 11 (2): 183-191.

KROGULEC E., SAWICKA K. 2015 - Groundwater protection in shale gas exploration areas - a Polish perspective. Episodes, J. Inter. Geosci., $38(1): 9-20$.

KROGULEC E., SAWICKA K. 2014 - Polish Experience with Groundwater Protection in Shale Gas Exploration Areas. OIL GAS European Magazine, 4 (40): 201-206.

KROGULEC E., SAWICKA K. 2013 - Optymalizacja organizacji sieci monitoringowych wód podziemnych $w$ rejonach poszukiwania i udostępniania złóż węglowodorów z formacji łupkowych. Biul. Państw. Inst. Geol., 456: 327-334.

PANDEY B., AGRAWAL M., SINGH S. 2015 - Ecological risk assessment of soil contamination by trace elements around coal mining area. J. Soils Sediment., 16 (1) : 159-168.

REIMANN C., DE CARITAT P. 2005 - Distinguishing between natural and anthropogenic sources for elements in the environment: regional geochemical surveys versus enrichment factors. Sci. Total Environ., 337 (1-3): 91-107.

ROZPORZĄDZENIE Ministra Zdrowia z dnia 7 grudnia 2017 r. w sprawie jakości wody przeznaczonej do spożycia przez ludzi. Dz.U. z 2017 r. poz. 2294.

ROZPORZĄDZENIE Ministra Gospodarki Morskiej i Żeglugi Śródlądowej z dnia 11 października 2019 r. w sprawie kryteriów i sposobu oceny stanu jednolitych części wód podziemnych. Dz.U. 2019 poz. 2148.

SELINUS O.S., ESBENSEN K. 1995 - Separating anthropogenic from natural anomalies in environmental geochemistry. J. Geochem. Expl., 55: 55-66.

SZALIŃSKA E., KOPERCZAK A., CZAPLICKA-KOTAS A. 2010 Badania zawartości metali ciężkich w osadach dennych dopływów Jeziora Goczałkowickiego. Ochr. Srod., 32 (1): 21-25. 